\title{
PENGARUH MODEL PEMBELAJARAN BERBASIS MASALAH TERHADAP HASIL BELAJAR SISWA PADA MATERI POKOK LISTRIK DINAMIS
}

\author{
Sundari Fitri dan Pintor Simamora \\ f3_sundari@rocketmail.com \\ Jurusan Fisika FMIPA Universitas Negeri Medan \\ Jalan Willem Iskandar Pasar V Medan, 20221
}

\begin{abstract}
ABSTRAK
Penelitian ini bertujuan untuk mengetahui pengaruh model pembelajaran berbasis masalah terhadap hasil belajar dan aktivitas siswa pada materi pokok Listrik Dinamis. Jenis penelitian ini adalah quasi experiment dengan populasi seluruh siswa kelas IX MTs Negeri 2 Rantauprapat yang terdiri dari 6 kelas. Dengan teknik cluster random sampling terpilih kelas $\mathrm{IX}_{\mathrm{B}}$ sebagai kelas eksperimen dan kelas $\mathrm{IX}_{\mathrm{A}}$ sebagai kelas kontrol. Setelah dilakukan pretes, kedua kelas diberi perlakuan yang berbeda, aktivitas siswa selama pembelajaran di kelas eksperimen dikategorikan aktif. Berdasarkan hasil uji hipotesis menggunakan uji t diperoleh bahwa ada perbedaan yang signifikan hasil belajar antara penerapan model pembelajaran berbasis masalah dengan pembelajaran konvensional dengan kata lain terdapat pengaruh model pembelajaran berbasis masalah terhadap hasil belajar siswa.
\end{abstract}

Kata Kunci : Model pembelajaran berbasis masalah, hasil belajar, aktivitas siswa.

\section{PENDAHULUAN}

Pendidikan sangat penting dalam kehidupan dan tidak dapat dipisahkan dari kehidupan. Majumundurnya suatu bangsa banyak ditentukan oleh pendidikan bangsa itu. Mengingat sangat pentingnya bagi kehidupan, maka pendidikan harus dilaksanakan sebaik-baiknya sehingga memperoleh hasil yang diharapkan.

Pendidikan adalah salah satu bentuk perwujudan kebudayaan manusia yang dinamis dan sarat perkembangan. Oleh karena itu, perubahan atau perkembangan pendidikan adalah hal yang memang seharusnya terjadi sejalan dengan perubahan budaya kehidupan. Perubahan dalam arti perbaikan pendidikan pada semua tingkat perlu terus menerus dilakukan sebagai antisipasi kepentingan masa depan. (Trianto, 2009:1)

Kegiatan pembelajaran merupakan kegiatan yang paling pokok Dalam keseluruhan proses pendidikan. Hal ini berarti bahwa berhasil tidaknya pencapaian tujuan pendidikan banyak bergantung kepada bagaimana proses belajar mengajar dirancang dan dijalankan secara profesional. Setiap kegiatan belajar mengajar selalu melibatkan dua pelaku aktif, yaitu guru dan siswa. Guru sebagai pengajar merupakan pencipta kondisi belajar 
siswa yang didesain secara sengaja, sistematis dan berkesinabungan. Sedangkan siswa sebagai subyek pembelajaran merupakan pihak yang menikmati kondisi belajar yang diciptakan guru. Perpaduan dari kedua unsur ini melahirkan interaksi edukatif dengan memanfaatkan bahan ajar sebagai mediumnya. Pada kegiatan belajar mengajar, keduanya (guru-murid) saling mempengaruhi dan memberi masukan. Karena itulah kegiatan belajar mengajar harus merupakan aktivitas yang hidup, sarat nilai dan senantiasa memiliki tujuan (Fathurrohman dan Sutikno, 2007:8).

Anak yang berhasil dalam belajar ialah yang berhasil mencapai tujuan-tujuan pembelajaran. Belajar juga merupakan suatu proses perubahan dari belum mampu ke arah sudah mampu dan proses perubahan itu dalam jangka waktu tertentu. Perubahan itu dapat berupa pengembangan pengetahuan, sikap, keterampilan yang diharapkan mampu memecahkan masalahmasalah akan tuntutan hidupnya. Karena itu seseorang dikatakan belajar bila diasumsikan di dalam diri orang tersebut telah terjadi suatu proses yang mengakibatkan perubahan tingkah laku. Kegiatan dan usaha untuk mencapi perubahan tingkah laku merupakan hasil belajar.

Hasil observasi menunjukkan bahwa sebagian siswa tidak menyukai pelajaran fisika. Siswa menganggap fisika merupakan pelajaran yang sulit dan tidak menyenangkan. Guru IPA yang mengajar di sekolah tersebut mengatakan bahwa nilai rata-rata ulangan fisika siswa masih rendah di bawah kriteria ketuntasan minimal sehingga untuk memperoleh ketuntasan dalam belajar, guru melakukan remedial. Dalam proses pembelajaran di kelas, biasanya guru membuka pembelajaran dengan mengabsen siswa, kemudian menjelaskan materi pembelajaran, menuliskan rumus dan memberikan contoh soal, selanjutnya siswa mengerjakan soal yang diberikan oleh guru. Sehingga proses pembelajaran berlangsung satu arah, siswa kurang aktif selama proses pembelajaran dan menjadi penerima informasi pasif.

Demi meningkatkan hasil belajar dalam bidang studi fisika maka diperlukan cara yang tepat untuk memotivasi siswa dan mengembangkan kreativitas serta sikap inovatif dari pendidiknya. Agar siswa aktif dalam proses pembelajaran, seorang guru harus mampu berhubungan dan berinteraksi secara baik dengan siswa sehingga dapat membuka wawasan berpikir, seperti melakukan diskusi dan melakukan eksperimen sehingga siswa mudah memahami materi yang diajarkan dan mengkaitkannya dalam kehidupan nyata. Untuk itu, penulis melakukan penelitian dengan menggunakan model pembelajaran berbasis masalah. Model pembelajaran berbasis masalah (PBM) merupakan inovasi dalam pembelajaran karena dalam PBM kemampuan berpikir siswa betulbetul dioptimalisasikan melalui proses kerja kelompok atau tim yang sistematis, sehingga siswa dapat memperdayakan, mengasah, menguji, dan mengembangkan kemampuan berpikirnya secara berkesinambungan 
Penelitian tentang PBM telah dilakukan oleh Tambunan (2014), diperoleh bahwa ada pengaruh hasil belajar siswa menggunakan model pembelajaran berbasis masalah. Pohan (2013) dalam skripsinya juga menyimpulkan bahwa ada perbedaan hasil belajar siswa pada materi pokok Listrik Dinamis dengan menerapkan model pembelajaran berbasis masalah. Astiti (2007) menyatakan bahwa aktivitas dan hasil belajar siswa mengalami peningkatan setelah melaksanakan pembelajaran dengan model PBM.

Adapun yang menjadi tujuan dalam penelitian ini adalah untuk mengetahui hasil belajar fisika siswa menggunakan model pembelajaran berbasis masalah dan pembelajaran konvensional, mengetahui pengaruh model pembelajaran berbasis masalah serta aktivitas belajar siswa selama proses pembelajaran menggunakan model pembelajaran berbasis masalah pada materi pokok Listrik Dinamis kelas IX MTs Negeri 2 Rantauprapat T.P 2014/2015.

Belajar pada hakikatnya adalah "perubahan" yang terjadi dalam diri seseorang setelah melakukan aktivitas tertentu. Walaupun pada kenyataannya tidak semua perubahan termasuk kategori belajar. Misalnya, perubahan fisik, mabuk, gilak dan sebagainya (Fathurrohman dan Sutikno, 2007:5-6).

Kegiatan peserta yang meliputi aktivitas jasmani dan aktivitas jiwa, antara lain: visual activities, oral activities, listening activities, writing activities, drawing activities, motor activities, mental activities dan emotional activities. Aktivitasaktivitas tersebut tidaklah terpisah atau satu sama lain. Dalam setiap aktivitas motoris terkandung aktivitas mental disertai oleh perasaan tertentu, dan seterusnya. Pada setiap pelajaran terdapat berbagai aktivitas yang dapat diupayakan. Prinsip aktivitas yang diuraikan di atas didasarkan pada pandangan psikologi bahwa, segala pengetahuan harus diperoleh melalui pengamatan sendiri dan pengalaman sendiri. Jiwa itu dinamis, memiliki energi sendiri, dan dapat menjadi aktif sebab didorong oleh kebutuhan-kebutuhan (Rohani, 2004:9)

$$
\text { Hasil belajar adalah }
$$

kemampuan yang diperoleh anak setelah melalui kegiatan belajar. Belajar itu sendiri merupakan suatu proses dari seseorang yang berusaha untuk memperoleh suatu bentuk perubahan perilaku yang relatif menetap. Dalam kegiatan belajar yang terprogram dan terkontrol yang disebut kegiatan pembelajaran atau kegiatan instruksional, tujuan belajar telah ditetapkan lebih dahulu oleh guru. Anak yang berhasil dalam belajar ialah yang berhasil mencapai tujuan-tujuan pembelajaran atau tujuan-tujuan instruksional (Abdurrahman, 2003:37-38).

Model pembelajaran adalah suatu rencana atau pola yang dapat digunakan untuk membentuk kurikulum (rencana pembelajaran jangka panjang), merancang bahanbahan pembelajaran, dan membimbing pembelajaran di kelas. Model pembelajaran dapat dijadikan pola pilihan, artinya para guru boleh memilih model pembelajaran yang sesuai dan efisien untuk mencapai tujuan pendidikannya.

Model pembelajaran berbasis masalah merupakan inovasi dalam 
pembelajaran karena dalam PBM kemampuan berpikir siswa betulbetul dioptimalisasikan melalui proses kerja kelompok atau tim yang sistematis, sehingga siswa dapat memberdayakan, mengasah, menguji, dan mengembangkan kemampuan berpikirnya secara berkesinambungan (Rusman, 2012:133-242).

Sintaks suatu pembelajaran berisi langkah-langkah praktis yang harus dilakukan oleh guru dan siswa dalam kegiatan. Adapun sintaks PBM dalam penelitian ini seperti ditunjukkan pada Tabel 1.

Tabel 1. Sintaks Pembelajaran Berbasis Masalah

\begin{tabular}{|c|c|}
\hline Tahap & Tingkah Laku Guru \\
\hline $\begin{array}{l}\text { Tahap } 1 \\
\text { Orientasi } \\
\text { siswa pada } \\
\text { masalah }\end{array}$ & $\begin{array}{l}\text { Guru menjelaskan } \\
\text { tujuan } \\
\text { pembelajaran, } \\
\text { menjelaskan } \\
\text { logistik yang } \\
\text { dibutuhkan, } \\
\text { mengajukan } \\
\text { fenomena atau } \\
\text { demonstrasi atau } \\
\text { cerita untuk } \\
\text { memunculkan } \\
\text { masalah, } \\
\text { memotivasi siswa } \\
\text { untuk terlibat } \\
\text { dalam pemecahan } \\
\text { masalah yang } \\
\text { dipilih. }\end{array}$ \\
\hline $\begin{array}{l}\text { Tahap } 2 \\
\text { Mengorganisa } \\
\text { si siswa } \\
\text { untuk belajar }\end{array}$ & $\begin{array}{l}\text { Guru membantu } \\
\text { siswa untuk } \\
\text { mendefinisikan dan } \\
\text { mengorganisasikan } \\
\text { tugas belajar yang } \\
\text { berhubungan } \\
\text { dengan masalah } \\
\text { tersebut. }\end{array}$ \\
\hline $\begin{array}{l}\text { Tahap } 3 \\
\text { Membimbing }\end{array}$ & $\begin{array}{l}\text { Guru mendorong } \\
\text { siswa untuk }\end{array}$ \\
\hline
\end{tabular}

\begin{tabular}{|c|c|}
\hline $\begin{array}{l}\text { penyelidikan } \\
\text { individual } \\
\text { maupun } \\
\text { kelompok }\end{array}$ & $\begin{array}{l}\text { mengumpulkan } \\
\text { informasi yang } \\
\text { sesuai, } \\
\text { melaksanakan } \\
\text { eksperimen dengan } \\
\text { masalah tersebut. }\end{array}$ \\
\hline $\begin{array}{l}\text { Tahap } 4 \\
\text { Mengembang } \\
\text { kan dan } \\
\text { menyajikan } \\
\text { hasil karya }\end{array}$ & $\begin{array}{l}\text { Guru membantu } \\
\text { siswa dalam } \\
\text { merencanakan dan } \\
\text { menyiapkan karya } \\
\text { yang sesuai seperti } \\
\text { laporan, video dan } \\
\text { model serta } \\
\text { membantu mereka } \\
\text { untuk berbagi tugas } \\
\text { dengan temannya. }\end{array}$ \\
\hline $\begin{array}{l}\text { Tahap 5 } \\
\text { Menganalisis } \\
\text { dan } \\
\text { mengevaluasi } \\
\text { proses } \\
\text { pemecahan } \\
\text { masalah }\end{array}$ & $\begin{array}{l}\text { Guru membantu } \\
\text { siswa untuk } \\
\text { melakukan refleksi } \\
\text { atau evaluasi } \\
\text { terhadap } \\
\text { penyelidikan } \\
\text { mereka dan proses- } \\
\text { proses yang mereka } \\
\text { gunakan. }\end{array}$ \\
\hline
\end{tabular}

\section{METODE PENELITIAN}

Penelitian ini dilaksanakan di MTs Negeri 2 Rantauprapat yang terletak di Jalan WR. Supratman No. $206 \mathrm{~km}$ 3,5 Rantauprapat. Populasi dalam penelitian ini adalah seluruh siswa kelas IX MTs Negeri 2 Rantauprapat T.P. 2014/2015. Pengambilan sampel dilakukan dengan cara cluster random sampling dengan mengambil 2 kelas dari kelas secara acak yaitu kelas $\mathrm{IX}_{\mathrm{B}}$ sebagai kelas eksperimen dengan penerapan model pembelajaran berbasis masalah yang berjumlah 23 orang dan kelas $\mathrm{IX}_{\mathrm{A}}$ sebagai kelas kontrol dengan pembelajaran konvensional yang berjumlah 24 orang.

Variabel dalam penelitan ini terdiri dari dua jenis yaitu: variabel 
bebas dan variabel terikat. Variabel bebas dalam penelitian ini adalah model pembelajaran berbasis masalah. Variabel terikat dalam penelitian ini adalah hasil belajar siswa pada materi pokok Listrik Dinamis.

Jenis penelitian ini adalah quasi experiment. Desain penelitian yang dipergunakan adalah two group pretest-posttest design. Desain penelitian ditunjukkan pada Tabel 2.

Tabel 2. Two group pretest-posttest

\begin{tabular}{|c|c|c|c|}
\hline \multicolumn{4}{c|}{ design } \\
\hline $\begin{array}{c}\text { Kretas } \\
\text { es }\end{array}$ & $\begin{array}{c}\text { Perlak } \\
\text { uan }\end{array}$ & $\begin{array}{c}\text { Post } \\
\text { es }\end{array}$ \\
\hline Eksperimen & $\mathrm{Y}_{1}$ & $\mathrm{X}_{1}$ & $\mathrm{Y}_{2}$ \\
Kontrol & $\mathrm{Y}_{1}$ & $\mathrm{X}_{2}$ & $\mathrm{Y}_{2}$ \\
\hline
\end{tabular}

Keterangan :

$\mathrm{Y}_{1}=$ Pretes

$\mathrm{X}_{1}=$ Pembelajaran dengan model pembelajaran berbasis masalah.

$\mathrm{X}_{2}=$ Pembelajaran konvensional.

$\mathrm{Y}_{2}=$ Postes

Instrumen yang digunakan dalam penelitian ini adalah tes hasil belajar dan lembar observasi aktivitas siswa. Adapun spesifikasi tes hasil belajar siswa pada materi pokok listrik dinamis sebanyak 20 soal pilihan berganda yang tersusun mulai dari $\mathrm{C}_{1}, \mathrm{C}_{2}, \mathrm{C}_{3}, \mathrm{C}_{4}, \mathrm{C}_{5}$ dan $\mathrm{C}_{6}$.

Uji normalitas dengan uji Lilliefors digunakan untuk mengetahui data kedua sampel beristribusi normal. Uji homogenitas digunakan untuk mengetahui apakah kedua sampel berasal dari populasi yang homogen. Uji homogenitas menggunakan uji kesamaan varians. Uji hipotesis dengan uji $t$ digunakan untuk mengetahui adanya pengaruh dari suatu perlakuan yaitu model pembelajaran berbasis masalah terhadap hasil belajar siswa. Uji peningkatan hasil belajar siswa pada materi pokok listrik dinamis dilakukan analisis hasil nilai pretes dan postes pada kelas eksperimen dan kelas kontrol. Analisis dilakukan dengan menggunakan normalitas gain.

\section{HASIL DAN PEMBAHASAN}

\section{a. Hasil Penelitian}

Sebelum diberi perlakuan, kelas eksperimen dan kelas kontrol dilaksanakan pretes untuk mengetahui kemampuan awal siswa. Hasil pretes kedua kelas dapat dilihat pada Gambar 1.

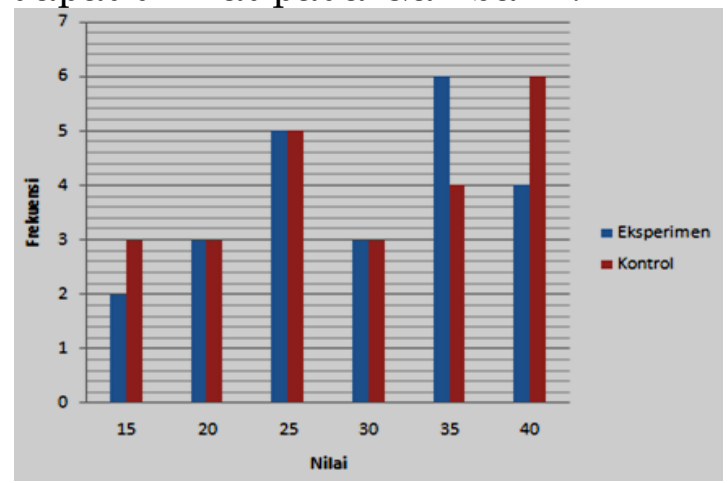

Gambar 1. Diagram batang nilai prestes kelas eksperimen dan kelas kontrol.

Gambar 1 menunjukkan bahwa nilai pretes pada kelas eksperimen dan kelas kontrol tidak jauh berbeda, artinya kedua kelas mempunyai kemampuan awal yang hampir sama dan perolehan nilai kedua kelas merata. Setelah memperoleh data hasil pretes siswa dari kedua kelas maka dilakukan uji normalitas dan homogenitas. Berdasarkan hasil uji normalitas diperoleh bahwa data pretes dari kedua kelas berasal dari populasi berdistribusi normal. Hasil uji homogenitas diperoleh bahwa sampel berasal dari populasi yang homogen sehingga dapat mewakili seluruh populasi yang ada. 
Setelah dilakukan pretes pada kedua kelas, selanjutnya kelas eksperimen diberi perlakuan dengan model pembelajaran berbasis masalah dan kelas kontrol dengan pembelajaran konvensional. Pembelajaran dilakukan sesuai dengan rencana pelaksanaan pembelajaran yang telah dibuat dengan materi pokok Listrik Dinamis.

Observasi aktivitas siswa dilakukan selama kegiatan pembelajaran berlangsung pada kelas eksperimen oleh 2 orang pengamat yang telah dilengkapi dengan lembar observasi. Jenis aktivitas yang diamati adalah : (1) visual, (2) oral, (3) listening, (4) writing, (5) motor, (6) mental, dan (7) emotional. Perkembangan aktivitas siswa di kelas eksperimen mengalami peningkatan selama menerima pembelajaran dengan menggunakan model pembelajaran berbasis masalah, dari pertemuan I yaitu $63.77 \%$ dengan kriteria cukup aktif, pertemuan II dengan rata-rata nilai $71.22 \%$ dengan kriteria aktif dan pertemuan III dengan rata-rata nilai $78.26 \%$ dengan kriteria aktif. Hasil observasi menunjukkan bahwa rata-rata skor aktivitas siswa pada selama pembelajaran mencapai $71.08 \%$ dengan kriteria Aktif. Perkembangan aktivitas belajar siswa dapat dilihat pada Gambar 2.

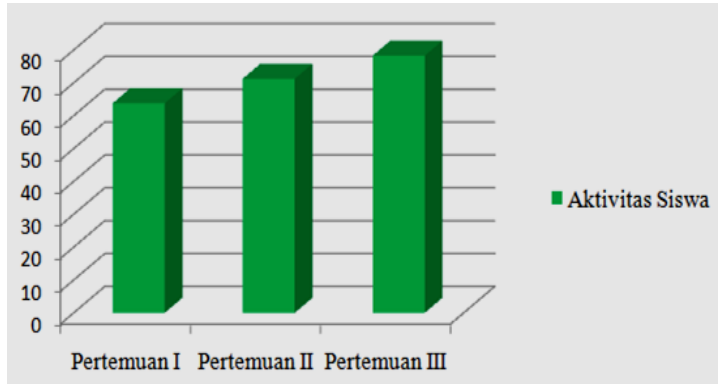

Gambar 2. Perkembangan Aktivitas Siswa di Kelas Eksperimen
Penilaian afektif berkenaan dengan sikap siswa selama kegiatan pembelajaran. Aspek afektif yang dinilai antara lain: logis, kritis, teliti, jujur dan berperilaku santun. Persentase nilai rata-rata afektif siswa selama pembelajaran di kelas eksperimen adalah $75.36 \%$ dengan kriteria baik.

Hasil belajar psikomotorik tampak dalam bentuk keterampilan (skill) dan kemampuan bertindak siswa. Aspek psikomorik yang dinilai antara lain: mempersiapkan alat dan bahan, merangkai percobaan, melakukan percobaan, mengamati percobaan, melakukan perhitungan dari percobaan dan menyimpulkan hasil percobaan. Presentase nilai rata-rata psikomotorik siswa selama pembelajaran di kelas eksperimen adalah $78.34 \%$ dengan kriteria baik.

Setelah diberikan perlakuan yang berbeda pada kedua kelas, selanjutnya dilakukan postes. Hasil postes kedua kelas dapat dilihat pada Gambar 3.

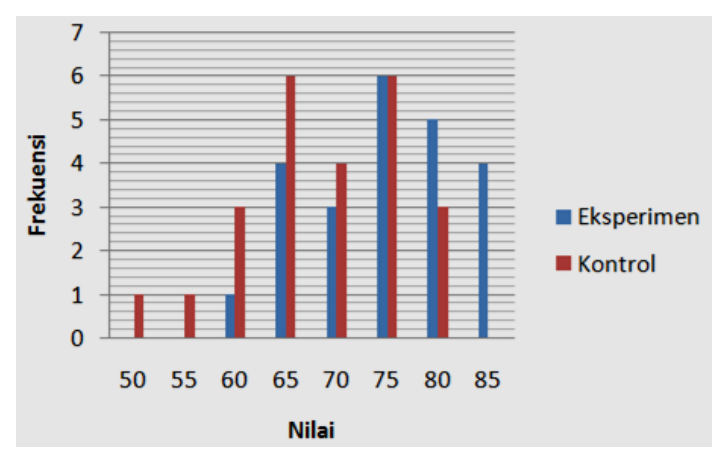

Gambar 3. Diagram batang nilai postest kelas eksperimen dan kelas kontrol.

Gambar 3 menunjukkan bahwa pada kelas eksperimen, nilai yang dicapai oleh siswa lebih tinggi dibandingkan pada kelas kontrol. Nilai Kriteria Ketuntasan Minimal (KKM) di MTs Negeri 2 
Rantauprapat adalah 70. Pada kelas eksperimen jumlah siswa yang memiliki nilai tergolong tuntas (mempunyai nilai $\geq$ nilai KKM) adalah 18 orang dan tidak tuntas ada 5 orang, sedangkan pada kelas kontrol jumlah siswa yang memiliki nilai tergolong tuntas ada 13 orang dan tidak tuntas ada 11 orang. Hal ini menunjukkan bahwa penerapan model pmbelajaran berbasis masalah baik untuk diterapkan.

Sebelum dilakukan uji hipotesis terlebih dahulu dilakukan uji prasyarat data postes yaitu uji normalitas menggunakan uji Lillifors dan uji homogenitas. Hasil uji normalitas diperoleh bahwa data postes dari kedua kelas berdistribusi normal. Pengujian homogenitas diperoleh bahwa sampel berasal dari populasi yang homogen sehingga dapat mewakili seluruh populasi yang ada. Kemudian dilakukan Uji t untuk mengetahui pengaruh dari suatu perlakuan. Hasil uji t untuk data postes diperoleh bahwa ada pengaruh model pembelajaran berbasis masalah terhadap hasil belajar siswa pada materi pokok Listrik Dinamis kelas IX MTs Negeri 2 Rantauprapat T.P 2014/2015.

Setelah diberikan perlakuan, peningkatan hasil belajar siswa pada kelas eksperimen dan kelas kontrol dapat dihitung dengan menggunakan normalitas gain. Hasil perhitungan normalitas gain menunjukkan bahwa peningkatan hasil belajar kelas eksperimen lebih besar dibandingkan dengan kelas kontrol.

\section{b. Pembahasan}

Data hasil penelitian memperlihatkan bahwa model pembelajaran berbasis masalah berpangaruh terhadap hasil belajar siswa. Keberhasilan model pembelajaran berbasis masalah didasarkan banyak hal yaitu model berbasis masalah ini menekankan kepada proses keterlibatan siswa secara penuh untuk dapat mengumpulkan informasi dari suatu masalah, melaksanakan eksperimen, dan berdiskusi secara kelompok untuk menemukan jawaban dari suatu masalah.

Keterampilan siswa dalam pembelajaran dengan menggunakan model pembelajaran berbasis masalah merupakan suatu proses yang bermula dari merumuskan masalah, merumuskan hipotesis, mengumpul data, melakukan pengujian, menganalisis data, dan membuat kesimpulan dari data yang diperoleh. Berdasarkan hasil penelitian dilapangan, model pembelajaran ini memiliki beberapa kelebihan:

1. Membuat guru dan siswa berperan aktif dalam pembelajaran. Guru menjadi lebih aktif berperan membimbing siswa, LKS sebagai alat bantu dalam pembelajaran dapat membuat siswa aktif dan tertarik melaksanakan seluruh kegiatan dalam proses pembelajaran.

2. Membantu siswa mengembangkan keterampilan berpikir dan pemecahan masalah.

3. Adanya kerjasama dalam kelompok untuk menyelasaikan permasalah yang diberikan.

4. Dengan adanya diskusi kelompok dan praktikum, siswa terbantu untuk memberikan hipotesis dari suatu masalah, mengumpulkan informasi, melakukan pengujian, 
menganalisis data dan membuat kesimpulan.

Namun demikian penerapan model pembelajaran berbasis masalah memiliki beberapa kendala dalam pelaksanaanya diantaranya adalah: 1) Pada awal pengerjaan rencanaan pelaksanaan pembelajaran, guru/peneliti mengalami kesulitan untuk mencari masalah yang sesuai dengan materi pembelajaran yang akan disajikan kepada siswa. 2) Pada tahap 3 model pembelajaran berbasis masalah, siswa cenderung ribut, banyak yang bertanya mengenai cara mengerjakan soal, merangkai alat dan bahan percobaan sehingga peneliti kerepotan untuk memberi bimbingan pada tiap kelompok. 3) Pada tahap 3 juga siswa menghabiskan banyak waktu untuk diskusi dan melakukan paraktikum.

Hasil penelitian ini sesuai dengan pendapat Trianto (2009:9697) bahwa PBM tidak dirancang untuk membantu guru memberikan informasi sebanyak-banyaknya kepada siswa. PBM dikembangkan untuk membantu siswa mengembangkan kemampuan berpikir, pemecahan masalah, dan keterampilan intelektualnya.

Menurut Rusman (2012:133-

242) Model pembelajaran berbasis masalah merupakan inovasi dalam pembelajaran karena dalam PBM kemampuan berpikir siswa betulbetul dioptimalisasikan melalui proses kerja kelompok atau tim yang sistematis, sehingga siswa dapat memberdayakan, mengasah, menguji, dan mengembangkan kemampuan berpikirnya secara berkesinambungan. Ditinjau secara umum, pembelajaran berbasis masalah terdiri dari menyajikan kepada siswa situasi masalah yang autentik dan bermakna yang dapat memberikan kemudahan untuk melakukan penyelidikan dan inkuiri. Interaksi antara stimulus dan respon, merupakan hubungan antara dua arah belajar dan lingkungan. Lingkungan memberi masukan kepada siswa berupa bantuan dan masalah yang dihadapi dapat diselidiki, dinilai, dianalisis serta dicari pemecahannya dengan baik. Pengalaman siswa yang diperoleh dari lingkungan akan menjadikan kepadanya bahan dan materi guna memperoleh pengertian serta bisa dijadikan pedoman dan tujuan belajarnya.

Hasil penelitian dengan menggunakan model pembelajaran berbasis masalah ini sesuai dengan penelitian sebelumnya yang dilakukan oleh Sihotang (2013) diperoleh rata-rata postes siswa di kelas eksperimen mencapai 66.42, sedangkan pada kelas kontrol hanya mencapai 34.43. Begitu juga Tambunan (2014) diperoleh ratarata postest siswa di kelas eksperimen mencapai 82.92 sedangkan pada kelas kontrol ratarata hasil postes hanya mencapai 67.68. Hal ini memperlihatkan bahwa ada pengaruh model pembelajaran berbasis masalah terhadap hasil belajar siswa. Model pembelajaran berbasis masalah dapat meningkatkan hasil belajar siswa dibandingkan dengn pembelajaran konvensional.

\section{KESIMPULAN DAN SARAN}

Berdasarkan hasil analisis
data penelitian maka dapat
disimpulkan bahwa ada pengaruh
model pembelajaran berbasis
masalah terhadap hasil belajar
siswa pada materi pokok listrik


dinamis kelas IX MTs Negeri 2 Rantauprapat T.P 2014/2015. Hal ini dilihat dari nilai rata-rata postes kelas eksperimen 74,78 dan nilai rata-rata postes kelas kontrol 68,54. Aktivitas belajar siswa dengan menggunakan model pembelajaran berbasis masalah diperoleh persentase skor $71.08 \%$ dengan kriteria aktif.

Berdasarkan hasil dan kesimpulan dalam penelitian, maka peneliti mempunyai saran: agar lebih memperhatikan dan membimbing siswa selama bekerja dalam kelompok dengan cara aktif bertanya kepada tiap siswa tentang apa yang telah dikerjakannya dalam kelompok, dengan begitu siswa akan lebih termotivasi untuk aktif dalam menyelesaikan tugas kelompok.

Hendaknya menjelaskan terlebih dahulu tahap-tahap pembelajaran, tugas yang akan dilakukan siswa dan mendemonstrasikan cara merangkai alat dan bahan praktikum sehingga peneliti tidak lagi menjelaskan pada tiap-tiap kelompok secara bergiliran sehingga tidak banyak waktu yang tersita pada proses tersebut.

\section{DAFTAR PUSTAKA}

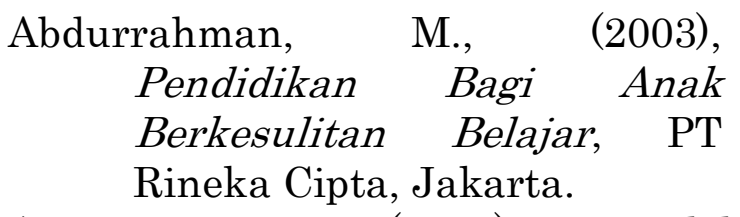
Astiti, F.Y., (2007), Model Pembelajaran Berbasis Masalah (Problem Based Learning) Untuk Meningkatkan Hasil Belajar Siswa Kelas VIII Semester II Smp N 5 Semarang Pokok Bahasan Bangun Ruang Sisi DatarTahun Pelajaran 2006/2007, Skripsi, FMIPA, Unnes Semarang.
Fathurrohman, P., Sutikno, S., (2007), Strategi Belajar Mengajar Melalui Konsep Umum dan Konsep Islami, PT Refika Aditama, Jakarta.

Pohan, A.F., (2013), Pengaruh Model Pembelajaran Berbasis Masalah Terhadap Hasil Belajar Siswa Pada Materi Pokok Listrik Dinamis Kelas IX SMP Negeri 5 Pematangsintar T.P 2013/2014, Skripsi, FMIPA Unimed Medan

Rohani, A., (2004), Pengelolaan Pengajaran, PT Rineka Cipta, Jakarta

Tambunan, D.S., (2014), Pengaruh Model Pembelajaran Berbasis Masalah Dengan Menggunakan Media Kartun Terhadap Hasil Belajar Siswa Pada Materi Pokok Gaya Dan Hukum-Hukum Newton Di Kelas VIII SMP Swasta An-Nizam Medan T.P 2013/2014, Skripsi, FMIPA Unimed Medan.

Trianto, (2009), Mendesain Model Pembelajaran Progresif, InovatifJakarta
Kencana, 